Jahangirnagar University J. Biol. Sci. 4(1): 71-80, 2015 (June)

\title{
Diversity and equitability of insect pests and natural enemies in brinjal field treated with insecticide
}

\author{
A. Awal ${ }^{1}$, M. M. Rahman, M. Z. Alam and M. M. H. Khan ${ }^{2 *}$ \\ Department of Entomology, Bangabandhu Sheikh Mujibur Rahman Agricultural \\ University, Gazipur-1706, Bangladesh
}

\begin{abstract}
Experiment was conducted during winter season to study the diversity and equitability of insect pest species and natural enemies in insecticide treated brinjal fields. Highest number of insect pests were recorded in` Tracer 45 SC, Bactoil (Bt), Nimbicidene 0.03 EC and lowest was in Necstar-50 EC and Proclaim-5 SG treated plots. The highest total abundance of insect pest was recorded in the plots treated with Bactoil and Tracer-45 SC and lowest total abundance was in Helicide (HNPV), Proclaim-5 SG and Booster-10 EC treated plots. The diversity index and equitability of insect pest species were highest in the plots treated with Nimbicidene 0.03 EC and Bactoil in visual search and sweep net methods while Bactoil and Booster $10 \mathrm{EC}$ in pitfall trap method. However, lowest diversity index and equitability were obtained from the plots treated with Booster 10 EC, Proclaim-5 SG, Necstar-50 EC, Tracer-45 $\mathrm{SC}$ in visual search and sweep net methods but also in plots treated with Nimbicidene 0.03 EC in pitfall trap method. In case of natural enemies, the highest number of families were recorded in Tracer-45 SC, Nimbicidine $0.03 \mathrm{EC}$ and Bactoil treated plots while lowest was in Helicide, Booster 10 EC, Proclaim-5 SG and Necstar-50 EC treated plots. The highest total abundance of natural enemy was recorded in the plot treated with Bactoil and Tracer-45 SC while lowest abundance was in the plot treated with Necstar-50 EC and Boster-10 EC. The diversity index and equitability of natural enemies were the highest in the plots treated with Proclaim-5 SG, Bactoil, Helicide and Necstar-50 EC in visual search, sweep net method and pitfall trap method while lowest was in Booster $10 \mathrm{EC}$, Tracer-45 SC treated plots in visual search method, Booster $10 \mathrm{EC}$ and Nimbicidene $0.03 \mathrm{EC}$ treated plots in sweep net method, Necstar-50 EC and Nimbicidene 0.03 EC treated plots in pitfall trap method. Bactoil and Tracer-45 SC were relatively safe for natural enemies and therefore would be fit well into integrated pest management (IPM) against BSFB of brinjal crop.
\end{abstract}

Key words: Diversity, equitability, insect pest, natural enemies, brinjal field

\section{INTRODUCTION}

In brinjal field in addition to brinjal shoot and fruit borer (BSFB) (Leucinodes orbonalis Guenee) as the major pest, various arthropod species both pests and natural enemies prevail from seedling to harvesting stage. EL-Shafie (2001) recorded 28 species of insect pests under 7 different insect orders from the brinjal ecosystem, while Nayer et al. (1995) reported 53 species of insect pests of brinjal. Many arthropod natural enemies of those obnoxious pests also exist in the same ecosystem (FAO 2003). Many researchers reported that insecticides killed other non-target arthropods, which caused serious ecological

\footnotetext{
${ }^{1}$ Upazilla Agriculture Officer, DAE, Arihazar, Narayanganj, Bangladesh

2 Department of Entomology, Patuakhali Science and Technology University Dumki, Patuakhali, Bangladesh

* Corresponding author. E-mail: mohasin1965@yahoo.com
} 
imbalance and affected arthropods biodiversity (Alam et al, 2006; Navntoft et al., 2006; Filho et al., 2004; Prijno et al., 2004; Rodriguez et al., 2003; Maleque et al., 1998). Tohnishi et al. (2005) reported that flubendiamide was highly toxic to Lepidopteran insect pests but it was very safe for different natural enemies like ladybird beetles, spiders, parasitic wasp, lacewings, predatory bug and predatory mite and might fit well into the integrated pest management (IPM). Several researchers reported that neem products are less harmfull to natural enemies (Schuster \& Stansly 2000, Smith \& Krischik 2000).

Bacillus thuringiensis are used against BSFB, Beauvaria bassiana, against Lepidopteran caterpillar, regarded as environmentally friendly, with little or no effect on human, wildlife, pollinators and most other beneficial insects. Nimbicidene and Flubebdiamite were comparatively safe for natural enemies and would be fitted well into the integrated pest management (IPM) programs for brinjal (Latif, 2007). Spinosad (Saccharopolyspora spinosa), relatively a new insecticide, which is toxic to a wide variety of insects and relatively non-toxic to mammals and beneficial insects (Anon, 2011b). Nuclear Polyhedrosis Virus (NPV), which belongs to the Baculoviruses, affects insects predominantly moth and butterflies. Viruses can affect a large number of pest species. However, they are extremely specific in the pest they can control (Anon. 2011c). Reports on the effects of other insecticides under study on natural enemies are not available, although studies on the effects of different insectisides on biodiversity have been carriedout at abroad. Therefore, it is important to know the effect of different selected insecticides on arthropod diversity including natural enemies for judging their suitability as eco-friendly component in the IPM package of BSFB. So the present study was undertaken to know the diversity and equitability of insect pests and natural enemies in insecticides treated brinjal field during winter season.

\section{MATERIALS AND METHODES}

The experiment was laid out in randomized complete block design (RCBD) with three replications in the experimental farm of Bangabandhu Sheikh Mujibur Rahman Agricultural University (BSMRAU), Gazipur during November 2009 to May 2010.

The whole field was divided into 3 blocks of equal size having space of 2 meters between blocks and 1.5 meters between plots. Each block was subdivided into 7 equal plots. The unit plot size was $3 \mathrm{~m} \times 3 \mathrm{~m}$ accommodating 15 pits per plot. The distance between rows was $1 \mathrm{~m}$ and that of plants was $60 \mathrm{~cm}$. The application of manures and chemical fertilizers was followed by the method described by Rashid (1993). Seeds of brinjal variety BARI brinjal-8 were collected from the Horticultural Research Center (HRC) of Bangladesh Agricultural Research Institute (BARI), Joydebpur, Gazipur. A small seed bed measuring $5 \mathrm{~m} \times 1 \mathrm{~m}$ was prepared and seeds were sown in the nursery bed at Experimental field of the Department Entomology, BSMRAU, on 7 October 2009. A total of 360 seedlings having 35 days old were planted in 21 plots @ 15 seedlings per plot with spacing row to row $1.00 \mathrm{~m}$ and seedling to seedling $60 \mathrm{~cm}$. Weeding in the plots was done as and when necessary. 
Treatments: $\quad \mathrm{T}_{1}=$ Bactoil $\left(\right.$ Bacillus thuringiensis, Bt) @ $2 \mathrm{ml} /$ liter, $\mathrm{T}_{2}=$ Helicide (Heliothis Nuclear Polyhedrosis Virus, HNPV) @ $0.5 \mathrm{ml} /$ liter, $\mathrm{T}_{3}=$ Nimbicidene 0.03 EC (Azadirachtin) @ $4 \mathrm{ml} /$ liter, $\mathrm{T}_{4}=$ Tracer-45 SC (Spinosad) @ $0.4 \mathrm{ml} /$ liter, $\mathrm{T}_{5}=$ Proclaim$5 \mathrm{SG}$ (Emamectin benzoate) @ $1 \mathrm{gm} /$ liter, $\mathrm{T}_{6}=$ Necstar-50 EC (Chlorpyriphos) @ 1 $\mathrm{ml} /$ liter and $\mathrm{T}_{7}=$ Boster-10 EC (Cypermethrin) @ $1 \mathrm{ml} / \mathrm{liter}$.

The insecticides were applied with the help of Knapsack sprayer. The first application of insecticides was started after $4^{\text {th }}$ week of transplanting and subsequent applications were made at 7 days intervals. Precautions were taken to avoid drift to the adjacent plots.

Data collection: The number of species was the simplest measure of diversity. However, for limitation in species identification, concept was restricted to order and family level. The counting of individual was performed by using visual search, sweep net and pitfall trap method. The number of insect pests and natural enemies were also collected and recorded.

Visual search method: Arthropods species comprising sessile, agile, adult, nymphs and larvae of flying insects on brinjal plants were counted from a random sample of 5 plants taken from each plot. For this purpose ten leaves were chosen randomly on each plant, four from the bottom (older leaves), two from the middle and four from the top (younger leaves). The lower surface of the leaves were thoroughly examined for the presence of insects. Counting was done before 08:30 hr (Bangladesh local time) to avoid the excessive mobility of the adult insects after this time, but nevertheless, the migration of the fast moving and mobile adults from one plot to the other could not be totally avoided. The data pooled over the season's average was combined to provide an overall average density per plot. The population density of each insect was expressed as number of individuals per 10 leaves of the plant. Individuals were counted from five branches selected randomly from 5 plants of each plot at weekly interval.

Sweep net method: This method was used for counting insects on brinjal plants to know the abundance pattern of brinjal plant dwelling insects. Five times return sweeping were done in each plot to make a composite sample by a sweep net at 15 days intervals. Each sample was examined separately without killing the insects and released them in the same plot immediately after counting. The individuals of each sample were identified up to family level.

Pitfall trap method: The pitfall trap method was used for the species that roam in the soil surface such as ground beetle, spiders, ants, earwig, crickets, centipedes, collembola etc. Small plastic pots having $10 \mathrm{~cm}$ diameter and $18 \mathrm{~cm}$ deep were used as pitfall traps. Three traps were placed in soil in each of the plots and the mouth of the pot was kept at ground level, so as not to obstruct insect movement. Each pot was then half filled with water and detergent as trapping fluid. After 24 hours of setting traps, the trapped arthropods were emptied with a seive and funnel into small plastic bottles filled to the half with $70 \%$ alcohol. The samples were labeled and stored until sorting, counting and finally were identified. Traps were set at 15 days intervals throughout the cropping season and insects were collected and counted separately from each plot. 
Measurement of diversity index and equitability: To assess the abundance pattern and the species richness in different insectcides treated plots, Simpson's diversity index was used (Simpson, 1949).

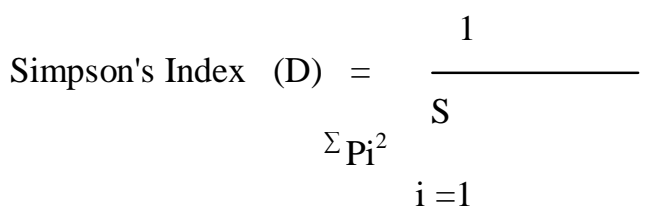

Where, $\mathrm{Pi}$ is the proportion of individual for the ith insect family and $\mathrm{S}$ is the total number of insect family in the community (i.e., the richness).

The value of index depends on both the richness and the evenness (equitability) with which individuals distributed among the families. Equitability was quantified by expressing Simpson's index, 'D' as a proportion of the maximum possible value of D.

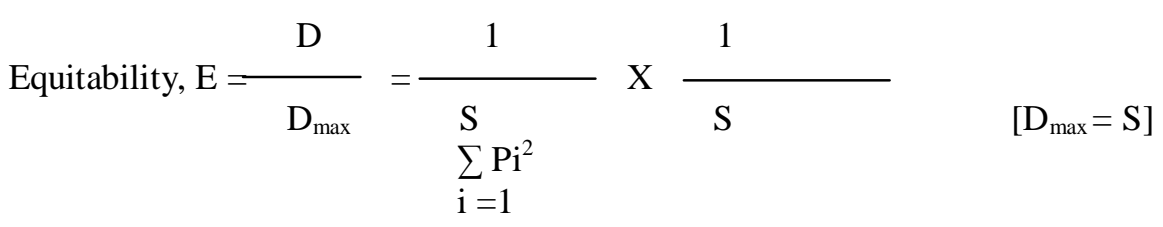

\section{RESULTS AND DISCUSSION}

Insect pest species observed through visual search method: Effects of seven insecticides on plant dwelling insect pests observed during winter through visual search method is presented in Table 1. The diversity index was the highest Nimbicidene $0.03 \mathrm{EC}$ (3.20) treated plots followed by Helicide (3.06), Bactoil (3.05), Tracer-45 SC (2.96), Proclaim-5 SG (2.00), and Necstar-50 EC (1.90) while it was the lowest (1.89) from the plots treated with Boster-10 EC. Though the total abundance of Boster-10 EC and Tracer$45 \mathrm{SC}$ were higher than Helicide and Nimbicidene $0.03 \mathrm{EC}$, their diversity indices were less than Helicide and Nimbicidene 0.03 EC, which indicate more abundance of some families in the plots treated with Boster-10 EC and Tracer-45 SC. The highest equitability 0.27 was recorded from the plots treated with Nimbicidene $0.03 \mathrm{EC}$ followed by Helicide (0.26), Bactoil (0.20, Tracer-45 SC (0.18), Necstar-50 EC and Boster-10 EC (0.16) while it was the lowest from Proclim-5 SG (0.13) which indicates the species richness of this treatment (Table 1).

Natural enemies observed through visual search method: The highest number of natural enemy families were recorded in Tracer-45 SC (8) treated plots followed by Nimbicidene 0.03 EC (6), Bactoil (6), Proclaim-5 SG (5) and Necstar-50 EC (4) while it was the lowest (3) in both Boster-10 EC and Helicide treated plots (Table 1). The highest number of natural enemy abundance was recorded in Bactoil (113.67) followed by Tracer-45 SC (103.33), Helicide (87.00), Nimbicidene 0.03 EC (86.33) and Proclaim-5 
SG (41.00) while it was the lowest (40.00) in both the plots treated, with Boster-10 EC and Necstar-50 EC. The highest diversity index was obtained in Proclaim-5 SG (2.92) followed by Tracer-45 SC (2.75), Nimbicidene 0.03 EC (2.74), Bactoil (2.71), Helicide (2.40) and Boster-10 EC (2.12) while it was the lowest (1.85) in Necstar-50 EC treated plots. The diversity index of Proclaim-5 SG was the highest among insecticides treated plots, though its' total abundance was lower, which indicates more abundance of some families compared to others.

Table 1. Diversity and equitability of insect pests and their naturan enemies in insecticides treated plots of brinjal field through visual searching method

\begin{tabular}{lccccc}
\hline Name of insecticides & No. of families & Total abundance & Diversity index & Equitability \\
\hline Bactoil (Bt) & $15.0(6.0)$ & $474.67(113.67)$ & $3.05(2.71)$ & $0.20(0.45)$ \\
Helicide (HNPV) & $12.0(3.0)$ & $343.33(87.00)$ & $3.06(2.40)$ & $0.26(0.80)$ \\
Nimbicidene 0.03 EC & $12.0(6.0)$ & $365.67(86.33)$ & $3.20(2.74)$ & $0.27(0.46)$ \\
Tracer-45 SC & $16.0(8.0)$ & $420.00(103.33)$ & $2.96(2.75)$ & $0.18(0.34)$ \\
Proclaim-5 SG & $15.0(5.0)$ & $347.67(41.33)$ & $2.00(2.92)$ & $0.13(0.58)$ \\
Necstar-50 EC & $12.0(4.0)$ & $353.67(40.00)$ & $1.90(1.85)$ & $0.16(0.46)$ \\
Boster-10 EC & $12.0(3.0)$ & $421.00(40.00)$ & $1.89(2.12)$ & $0.16(0.71)$ \\
\hline
\end{tabular}

Data in parenthesis represents corresponding number of natural enemies.

The highest equitability (0.80) was recorded in the plots treated with Helicide followed by Boster-10 EC (0.71), Proclaim-5 SG (0.58), Nimbicidene 0.03 EC (0.46), Necstar-50 EC (0.46), Bactoil (0.45) while it was the lowest in Tracer-45 SC (0.34) which indicates species richness of natural enemy of these treatments (Table 1).

From the Table 1, it was revealed that treatments Bactoil, Nimbicidene 0.03 EC, Helicide and Tracer-45 SC (Spinosad) showed lower equitability i.e; higher species richness of natural enemy biodiversity specially in case of visual search method and may be fit well into the IPM package.

Insect pest species observed through sweep net method: The highest number of insect pest families was recorded in Bactoil treated plots (27) followed by Tracer-45 SC (25), Nimbicidene 0.03 EC (22), Helicide (17), Necstar-50 EC (13) and Boster-10 EC (12) while it was the lowest (11) in the plots treated with Proclaim-5 SG (Table 2). The highest numbers of arthropods were recorded in the plots treated with Bactoil (178.33) followed by Nimbicidene 0.03 EC (154.00), Helicide (142.00), Necstar-50 EC (135.33), Boster-10 EC (121.33) and Tracer-45 SC (117.67) while it was the lowest (109.33) in the plots treated with Proclaim-5 SG (Table 3). The diversity index was the highest (6.03) in the plots treated with Bactoil followed by untreated control plots (5.00), Nimbicidene 0.03 EC (3.70), Helicide (3.52) and Tracer-45 SC (3.14). Bactoil treated plots showed higher diversity index though its' total abundance was less compared to other treatments, which indicates more abundance of some families of this treatment. The highest equitability 0.22 was recorded in the plots treated with Bactoil followed by Helicide (0.21), Proclaim-5 SG (0.18), Boster-10 EC (0.17) and Necstar-50 EC (0.15) while it was the lowest in Tracer- 
$45 \mathrm{SC}(0.13)$. The lower equitability indicates higher species richness of this treatment (Table 2).

Natural enemies observed through sweep net method: The highest number of natural enemy families (11) was recorded in plots treated with Nimbicidene $0.03 \mathrm{EC}$ followed by Tracer-45 SC (10), Bactoil (10) and Boster-10 EC (4) while it was the lowest (3) in the plots treated with Necstar-50 EC and Proclaim-5 SG. The highest number of natural enemy abundance was recorded in the plots treated with Bactoil (64.67) followed by Nimbicidene 0.03 EC (41.33), Helicide (38.33), Tracer-45 SC (34.65), Necstar-50 EC (17.33) and Proclaim-5 SG (15.67) while it was the lowest (15.00) in the plots treated with Boster-10 EC (Table 2).

Table 2. Diversity and equitability of insect pests and their natural enemies in insecticides treated plots of brinjal field through sweep net method

\begin{tabular}{lccccc}
\hline Treatments & No. of families & Total abundance & Diversity index & Equitability \\
\hline Bactoil (Bt) & $27.0(10.0)$ & $178.33(64.67)$ & $6.02(4.19)$ & $0.22(0.42)$ \\
Helicide (HNPV) & $17.0(8.0)$ & $142.00(38.33)$ & $3.52(3.61)$ & $0.21(0.45)$ \\
Nimbicidene 0.03 EC & $22.0(11.0)$ & $154.00(41.33)$ & $3.70(3.95)$ & $0.17(0.36)$ \\
Tracer-45 SC & $25.0(10.0)$ & $117.67(34.65)$ & $3.14(3.74)$ & $0.13(0.37)$ \\
Proclaim-5 SG & $11.0(3.0)$ & $109.33(15.67)$ & $2.03(2.59)$ & $0.18(0.86)$ \\
Necstar-50 EC & $13.0(3.0)$ & $135.33(17.33)$ & $1.99(2.61)$ & $0.15(0.87)$ \\
Boster-10 EC & $12.0(4.0)$ & $121.33(15.00)$ & $2.04(2.55)$ & $0.17(0.64)$ \\
\hline
\end{tabular}

Data in parenthesis represents corresponding number of natural enemies.

The diversity index was the highest (4.19) in the plots treated with Bactoil followed by Nimbicidene (3.95), Tracer-45 SC (3.74), Helicide (3.61), Necstar-50 EC (2.61) and Proclaim-5 SG (2.59) while it was the lowest (2.55) in the plots treated with Boster-10 EC which were positively related with total abundance of natural enemy of the treatments except treatment Tracer-45 SC. Total abundance of treatment Tracer-45 SC was less than treatment Helicide but its diversity index was higher than Helicide, which indicates more abundance of some families of this treatment. The highest equitability (0.87) was recorded from the plots treated with Necstar-50 EC followed by Procliam-5 SG (0.86), Boster-10 EC (0.64), Bactoil (0.42), Tracer-45 SC (0.37) and Nimbicidene 0.03 EC (0.36) while it was the lowest (0.34) from untreated control plots. The lower equitability indicates higher species richness of natural enemy (Table 2).

From the Table 2, it was revealed that treatments with Bactoil, Nimbicidene $0.03 \mathrm{EC}$ and Tracer-45 SC showed lower equitability i.e; higher species richness irrespective of seasons especially in case of natural enemy biodiversity and may be fitted well into the IPM package.

Insect pest species observed through pitfall trap method: The highest number of arthropods families (12) was recorded in plots treated with Nimbicidene 0.03 EC and Bactoil followed by Tracer -45 SC (10), Helicide (9), Proclaim-5 SG and Boster-10 EC 
(8) while it was the lowest (7) from the plots treated with Necstar-50 EC. The highest number of arthropods was recorded in Tracer-45 SC (56.67) followed by Bactoil (56.33), Nimbicidene 0.03 EC (53.33), Proclaim-5 SG (23.33) and Necstar-50 EC (22.00) while it was the lowest (20.67) in the plots treated with Boster-10 EC (Table 3). The highest diversity index was observed in Bactoil (3.88) followed by Tracer-45 SC (3.69), Boster10 EC (3.18), Proclaim-5 SG (2.88), Nimbicidene 0.03 EC (2.86) and Helicide (2.66) while it was the lowest (2.66) in the plots treated with Necstar-50 EC. The diversity indedx of Boster-10 EC was relatively higher though its total abundanc was the lowest, which indicates more abudance of some families than the others. The highest equitability (0.40) was recorded in the plots treated with Boster-10 EC followed by $0.38,0.370 .36$ and 0.36 in the plots treated with Necstar-50 EC, Tracer-45 SC and Proclaim-5 SG, respectively. while it was the the lowest $(0.24)$ in the plots treated with Nimbicidene 0.03 EC. The lower equitability indicates higher species richness of the treatments (Table 3).

Natural enemies observed through pitfall trap method: The highest number of natural enemy families (10.00) was recorded in Bactoil treated plots followed by the plots treated with Nimbicidene 0.03 EC (9.00), in Booster (6.00), Helicide (6) and Proclaim-5 SG (5.00) while it was the lowest (4.00) in the plots treated with Necstar-50 EC (Table 3). The highest number of natural enemy abundance was recorded in Tracer-45 SC (54.67) followed by Bactoil (54.33), Proclaim-5 SG (21.00) and Necstar-50 EC (19.67) while it was the lowest (19.33) in the plots treated with Boster-10 EC (Table 6). The diversity index was the highest in Bactoil (3.61) followed by Tracer-45 SC (3.49), Helicide (2.48), Nimbicidene 0.03 EC (2.46) and Proclaim-5 SG (2.34) while it was the lowest (2.12) from the plots treated with Necstar-50 EC (Table 3).

Table 3. Diversity and equitability of insect pests and their natural enemies in insecticides treated plots of brinjal field through Pitfall trap method

\begin{tabular}{lcc|cc}
\hline Treatments & No. of families & Total abundance & Diversity index & Equitability \\
\hline Bactoil (Bt) & $12.0(10.0)$ & $56.33(54.33)$ & $3.88(3.61)$ & $0.32(0.36)$ \\
Helicide (HNPV) & $9.0(6.0)$ & $43.33(40.67)$ & $2.81(2.48)$ & $0.31(0.41)$ \\
Nimbicidene 0.03 EC & $12.0(9.0)$ & $53.33(49.33)$ & $2.86(2.46)$ & $0.24(0.27)$ \\
Tracer-45 SC & $10.0(9.0)$ & $56.67(54.67)$ & $3.69(3.49)$ & $0.37(0.39)$ \\
Proclaim-5 SG & $8.0(5.0)$ & $23.33(21.00)$ & $2.88(2.34)$ & $0.36(0.47)$ \\
Necstar-50 EC & $7.0(4.0)$ & $22.00(19.67)$ & $2.66(2.12)$ & $0.38(0.53)$ \\
Boster-10 EC & $8.0(6.0)$ & $20.67919 .33)$ & $3.18(2.76)$ & $0.40(0.46)$ \\
\hline
\end{tabular}

Data in parenthesis represents corresponding number of natural enemies.

The highest equitability (0.53) was recorded in the plots treated with Necstar-50 EC followed by Procliam-5 SG (0.47), Boster-10 EC (0.46), untreated control plots (0.43), Tracer-45 SC (0.39, and Bactoil (0.36) while it was the lowest (0.27) from Nimbicidene $0.03 \mathrm{EC}$ treated plots. The lower equitability indicates higher species richness of natural enemy biodiversity (Table 3 ). 
From the Table 3, it was revealed that treatments with Bactoil, Nimbicidene 0.03 EC, Tracer-45 SC and Helicide showed lower equitability i.e; higher species richness specially in case of natural enemy biodiversity through pitfall trap method and may be fitted well into the IPM package. The findings of the present study are in conformity with several workers. Sauphanor et al. (1995) reported that Azadirachtin is relatively harmless to spiders, butterflies and insects such as bees that pollinate crops and trees, ladybirds that consume aphids and wasps that act as parasitoid on various crop pests. In a few trials, negative effects have been noted on immature stages of beneficial species exposed to neem products. However, neem products are generally thought to be suitable for inclusion into integrated pest management programs (Banken \& Stark 1997).

A field study has confirmed the general low activity of Spinosad for many beneficial insect species. Spinosad was harmless to Poecilus cupreus (ground dwelling predator) and had limited adverse effects on Episyrphus balteatus and Coccinella septempunctata (foliage dwelling predators). Against another foliage dwelling predator, Chrysoperla carnea, Spinosad was harmless at $36 \mathrm{~g}$ ai/hL in an extended laboratory study involving realistic application methods (Anon. 2012). Spinosad (Saccharopolyspora spinosa) relatively a new insecticide that is toxic to a wide variety of insects and relatively non toxic to mammals and beneficial insects (Anon. 2011b). Field studies with Spinosad in which bees have been introduced the day following applications to orchards have also demonstrated the lack of Spinosad impacts. Applications of Spinosad to alfalfa fields, in which honeybee hives were covered for the first 3 hours post-application, also demonstrated no adverse effects to honeybees or leafcutter bees (Saunders \& Bret 2012). Giolo et al. (2005) reported that Vermitec 18 EC $(0.001 \%)$ (Abamectin) were harmful to Trichramma atopovirilia. No harmful effect was detected on larvae and pupae of this species inside the host egg. Low toxicity of newer insecticides (Imidacloprid, Spinosad and Thiodicarb) was observed by Boyd \& Boethel (1998) against predacious Hemipteran species of soybean lopper. They found greater toxicity of Cypermethrin and Methyl parathion against those predators and demonstrated that most of the newer insecticides were more selective than the older insecticides. Alam et al. (2003) observed very low or non-existence of Trathala flavo-orbitalis, a larval-pupal parasitoid of BSFB in pesticides sprayed field. Dutton et al. (2003) performed tritrophic experiments with S. littoralis and the spider mite Tetranychus urticae (Koch) (Acari: Tetranychidae), which is not susceptible to Bt toxins. Although adverse effects were found in lacewing larvae fed $S$. littoralis, there was no effect on larvae fed the tolerant prey, suggesting that the detrimental effects observed when lacewing larvae were fed $B$. thuringiensis-treated $S$. littoralis larvae were due to the quality of the prey and not to a direct toxic effect of the $\mathrm{Bt}$ toxin. The specific activity of Bt generally is considered highly beneficial. Unlike most insecticides, Bt insecticides do not have a broad spectrum of activity, so they do not kill beneficial insects. Therefore, Bt integrates well with other natural controls. Nimbicidene and flubendiamide were less harmful to arthropods species and natural enemies, while Abamectin was moderately harmful insecticide to the arthropods diversity in the brinjal ecosystem (Latif, 2007). 


\section{REFERENCES}

Alam, S. N., Rashid, M. A., Rouf, F. M. A., Jhala, R. C., Patel, J. R., Satpathy, S., Shivalingaswamy, T. M., Rai, S., Wahundeniya, I., Cork, A., Ammaranan, C. and Talekar, N. S. 2003. Development of an integrated pest management strategy for eggplant fruit and shoot boreer in South Asia. Technical Bulletin 28. AVRDC-The World Vegetable Center, Shanhua, Taiwan. 66p.

Alam, S. N., Hossain, M. I., Rouf, F. M. A., Jhala, R. C., Patel, M. G., Nath, L. K., Sengupta, A., Baral, K., Shylesha, A. N., Satpathy, S., Shivalingaswamy, T. M., Cork, A. and Talekar N. S. 2006. Control of eggplant shoot and fruit borer in South Asia. Technical Bulletin 36, AVRDC- The World Vegetable Center, Shanhua, Taiwan. 88p.

Anonymous. 2011a. www.en.wikipedia.org/wiki/bacillus thuringiensis.

Anonymous. 2011b. www.livingwithbug.com/spinosad.html.

Anonymous. 2011c. www.cas.muohio.edu/mbi-ws/microbialpestcontrol/virus.htm.

Anonymous 2012. http://www.hort.uconn.edu/ipm/general/htms/spinosad.htm

Banken, J. O. and Stark, J. D. 1997. Stage and age influence on Susceptibility of Coccinella septempunctata after direct exposure to Neemix, a neem insecticide. J. Econ. Entomol. 90(5): 1102-1105.

Boyd, M. L, and Boethel. D. J. 1998. Susceptibility of predaceous Hemipteran species to selected insecticides on soybean in Louisiana, J. Econ. Entomol. 91(2): 401-409.

Dutton, A., Klein, H. Romeis, J. and Bigler, F. 2003. Prey-mediated effects of Bacillus thuringiensis spray on the predator Chrysoperla carnea in maize. Biol. Control 26:209215.

El-Shafie, H. A. F. 2001. The use of neem products for sustainable management of Homopterous key pests on potato and eggplant in Sudan. Ph. D. Thesis, Institute of Phytopathology and Applied Zoology Experimental station Justus Liebig University of Giessen, Germany. $165 \mathrm{p}$.

FAO (Food and Agricultural organization). 2003. Inter country programme for integrated pest management in vegetables in south and South-East Asia. Eggplant integrated pest management: An ecological guide. 177p.

Filho, M. M., Guedes, R. N. C., Della-Lucia, T. M. C., Michereff, M. F. F. and Cruz, I. 2004. Nontarget impact of chlorpyriphos on soil arthropods associated with no-tillage cornfields in Brazil. International J. of Pest Management. 50(2): 91-99.

Giolo, F. P., Grutzmacher, A. D., Manzoni, C. G., Nornberg, S. D., Muller, C. and Harter, W. R. 2005. The side effects of pesticides used in integrated production of peaches on adults of Trichogramma atopovirilia Otman \& Platner (Hymenoptera: Trichogrammatidae). Egg parasitoid News. 17: 26-30.

Latif, M. A. 2007. Ph. D. Dissertation on, "Effectiveness of some insecticides in managing brinjal shoot and fruit borer, Leucinodes orbonalis Guenee and their impact on arthropod biodiversity and soil microbial respiration", Bangabandhu Sheikh Mujibur Rahman Agricultural University (BSMRAU), Salna, Gazipur, Bangladesh.

Maleque, M. A., Islam, M. N., Kundu, R. and Islam, M. S. 1998. Judicious use of insecticides for the management of the brinjal shoot and fruit borer. Bangladesh J. Entomol. 8(1-2): 97107.

Navntoft, S., Esbjerg, P. and Riedel, W. 2006. Effects of reduced pesticide dosages on carabids (Coleoptera: Carabidae) in winter wheat. Agril. and Forest Entomol. 8(1): 57-62. 
Nayar, K. K., Ananthakrishnan, T. N. and David, B. V. 1995. General and Applied Enotmology. $11^{\text {th }}$ edn. Tata MeGraw-Hill Publ. Co. Ltd. 4/12, Asaf Ali Road, New Delhi-110002. pp. 557.

Prijno, D., Robinson, M., Rauf, A., Bjorksten, T. and Hoffmann, A. A. 2004. Toxicity of chemicals commonly used in Indonesian vegetable crops to Liriomyza huidobrensis populations and the Indonesian parasitoiods Hemiptarsenus varicornis, Opius sp. and Gronotoma micromorpha, as well as the Australian parasitoids Hemiptarsenus varicornis and Diglyphus isaea. J. Econ. Entomol. 97(4): 1191-1197.

Rashid, M. M. 1993. Begum Paribarer Shabji. In: Shabji Biggan (in Bangla). First Edn. Bangla Academy, Dhaka, Bangladesh.

Rodriaguez. E., Pena, A., Raya, A. J. S. and Compos, M. 2003. Evaluation of the effect on arthropod populations by using deltamethrin to control Phloeotribus scarabaeoides Bern (Coleoptera: Scolytidae) in olive orchards. Chemosphere. 52(1): 127-134.

Saunders, D. G. and Bret, B. L. 2012. "Fate of Spinosad in the Environment." Down to Earth, Spinosad Technical Bulletin, 52:14-20 (1997).

Sauphanor, B., Lenfant C. and Sureau, F. 1995. Effects d'un extrait de neem (Azadirachta indica A. Juss) sur le development de Forficula auricularia L. (Dermaptera). J. Appl. Ent. 119: 215-219.

Schuster, D. J. and Stansly, P. A. 2000. Response of two lacewing species to biorational and broad-spectrum insecticides. Phytoparasitica 28: 297-304.

Simpson, E. D. 1949. Measurement of diversity, nature. 163: 688.

Smith, F. K. and Krischik, V. A. 2000. Effect of biorational pesticides on four coccinellid species (Coleoptera: Coccinellidae) having potential as biological control agents in interiorscape. J. Econ. Entomol. 93: 732-736.

Tohnishi, M., Nakao, H., Furuya, T., Seo, A., Kodama, H., Tsubata, K., Fujioka, S., Hirooka, S. and Nishimatsu, T. 2005. Flubendiamide, a novel insecticide highly active against Lepdopterous insect pests. J. Pestic. Sci. 30(4): 354-360. 